\title{
Recycling of Fermented Brine in Citron Curing'
}

\author{
L. E. Cancel and E. R. de Hernández ${ }^{2}$
}

\begin{abstract}
Fermented brine in citron curing was recycled successfully by centrifugation at $12,000 \mathrm{r} / \mathrm{m}$ of the used solution to remove suspended material, and then adding salt to the desired level of concentration. Eleven consecutive fermentations using the recylced brine produced good cured citron. Brine reusal in citron curing makes three important contributions to the citron curing industry: 1) It shortens fermentation time to about two days; 2) it can save about 78 percent of the salt used; 3 ) it eliminates the brine waste disposal problem.
\end{abstract}

\section{INTRODUCTION}

Fermentation of citrons and cucumbers is conducted in brine. The process is characterized by prolonged periods of curing during which numerous microbiological, chemical, and physical changes take place $(1,2,4,5)$. The curing of both citrons and cucumbers can be divided into two steps: a) initial phase or fermentation period during which the fruit or vegetable pulp is conditioned or modified for further candying or pickling, and b) a brine storage period before the final operation of candying and/or pickling. The initial phase or fermentation period in both cases takes a minimum of 5 to 10 days by adjusting the concentration and the temperature of the brine. The period may be extended several months, however, if proper conditions are not maintained.

Citron fruit is sliced in halves or diced to the desired size and placed in a salt solution (brine) for fermentation. This process removes the bitterness, clears the mesocarp, softens the tissues, and makes it possible to absorb high concentrations of sugar. The fermented citron is drained from the brine and desalted for the candying operation. It can also be placed in a freshly prepared brine solution for storage.

The process of curing citron is in need of updating using modern processing techniques regarding standardization of the fermentation period and the disposal of the brine solution.

Studies were initiated and oriented to develop a shorter period of fer-

1 Manuscript submitted to Editorial Board October 15, 1974.

2 Food Scientist and Assistant Food Scientist, respectively, Food Technology Laboratory, Agricultural Experiment Station, Mayagüez Campus, University of Puerto Rico, Río Piedras, P.R. 
mentation while eliminating the brine disposal problem. The results of the study are presented herein.

\section{MATERIALS AND METHODS}

\section{CITRONS}

Commercial citrons were obtained in Adjuntas and sorted according to maturity. Green fruit was selected for use in the fermentation studies. Fruit size varied from $2 \times 4$ inches to $5 \times 9$ inches, the average diameter about twice the length. After sorting, the fruits were washed by dipping in water at $120^{\circ} \mathrm{F}\left(48.9^{\circ} \mathrm{C}\right)$ for $20 \mathrm{~min}$, dried well, and stored at $45^{\circ} \mathrm{F}\left(7.2^{\circ}\right.$ C).

\section{FRUIT PREPARATION}

Citrons for fermentation studies were prepared in three forms: whole, sliced in halves, and diced into $1 / 2$ inch cubes. For cut and diced citrons, the fruits were first sliced longitudinally in halves. Endocarp (juice sacs and seeds) was removed with an electric paring machine. Diced fruit was prepared in an Urshel Model G machine ${ }^{3}$ equipped with a 1/2-inch dicing accessory. Fruit pieces $3 \times 5$ inches or larger had to be quartered before feeding into the dicing machine.

\section{FERMENTATION}

Citrons were fermented in a brining solution of 10 percent sodium chloride and 0.2 percent calcium chloride in 10-gallon stainless steel tanks. This solution has a specific gravity of 1.061 and a salometer reading of $30^{\circ}$. Ambient temperature varied from $81^{\circ} \mathrm{F}\left(27.2^{\circ} \mathrm{C}\right)$ to $93^{\circ} \mathrm{F}\left(32.4^{\circ} \mathrm{C}\right)$ with an average value of $88^{\circ} \mathrm{F}\left(31.1^{\circ} \mathrm{C}\right)$. In controlling the fermentation the following determinations were made: specific gravity, $\mathrm{pH}$, degrees salometer, and percent acidity expressed as lactic acid. Microbiological counts were made every 24 hours to determine bacteria, molds and yeasts in the fermenting media.

Whole fruits were fermented for 6 months; halves, 28 days. Both sizes were checked daily for salt concentration, acidity and pH.

Diced fruit was fermented on the basis of the pre-set schedule; $7,4,3$ and 2 days. Daily checks were made for $\mathrm{pH}$, percent acidity, degrees salometer and specific gravity. At the end of each fermentation period, the fermented citron were drained and the brine centrifuged in a Westfalia Sepa-

3 Trade names in this publication are used for the sole purpose of providing specific information. Mention of a trade name does not constitute a guarantee or warranty of the equipment by the authors or the Agricultural Experiment Station of the University of Puerto Rico or an endorsement over other equipment not mentioned. 
rator (Model AG-LWA-205) at 12,000 r/m to remove suspended material (pulp and microbial growth). Solids separated were weighed and the brine stored in a freezer $-10^{\circ} \mathrm{F}\left(-23.3^{\circ} \mathrm{C}\right)$ for the next fermentation.

Our study involved three series of experiments. Eleven fermentations were carried out in each series using the same brine. The following fermentations were made for each series, 2 periods of 7 days each, 3 periods of 4 days each, and 3 periods of 2 days each. The fermented citron was candied and evaluated to check on performance of each of the processes under study.

\section{CANDYING PROCESS}

To candy the fermented citron, fruits were first desalted in two 5-min immersions in water at $210^{\circ} \mathrm{F}\left(98.9^{\circ} \mathrm{C}\right)$. Weight of water used was twice that of the fruit. The desalted fruit was drained and placed in a stainless steel steam kettle with an amount of water $11 / 2$ times the weight of the citron, plus sugar and glucose in a 1:1 proportion to obtain an initial concentration of $21^{\circ}$ Brix. The temperature of the sweetening syrup was maintained between $140^{\circ} \mathrm{F}\left(60^{\circ} \mathrm{C}\right)$ and $160^{\circ} \mathrm{F}\left(71.1^{\circ} \mathrm{C}\right)$. Constant agitation was provided during the process at a speed of $16 \mathrm{r} / \mathrm{m}$. The sugar concentration was raised hourly by adding equal amounts of sugar and glucose in quantities sufficient to increase the Brix in stages of 3 to 4 degrees until it reached $72^{\circ}$, taking about two days. The candied citron remained overnight in the $72^{\circ} \mathrm{Bx}$ syrup, drained the next day, dipped quickly in cold water and drained again, then dried in open trays in an air conditioned room $\left(66^{\circ} \mathrm{F}\left(18.9^{\circ} \mathrm{C}\right)\right.$ and 49 percent relative humidity) for 24 hours.

\section{RESULTS AND DISCUSSION}

The fermentation of whole and halved citrons produced, as expected, a candied citron of good commercial quality, as these are the standard industrial processes. The candied diced citron produced from fermentation periods of $2,3,4$, and 7 days was evaluated by comparison with the standard product. The latter products were found to be of better quality as they possess a more pronounced citron flavor, the green pulp is a purer green and the translucent non-colored pulp is almost without a trace of the brownish tint found in the product prepared by the industrial process now in current use.

Citron curing has not been studied as thoroughly as the cucumber fermentation process used in the pickle industry. Due to the similarity existing in the fermentation phase in both industries we will compare the results of our investigations with those made with cucumbers.

Changes in pH (fig. 1) in the fresh brine fermentation in our work followed the same trend given by Jones (6) in his work with cucumbers. An 
initial high $\mathrm{pH}$ due to the ingredients placed in the fermenting vat followed by a drop in $\mathrm{pH}$ and a levelling off at a value of about 3.5. The $\mathrm{pH}$ in the fermentations where the brine is recycled maintained an almost constant value. This is to be expected as the acid and buffering substances are already in the solution.

Acid formation (fig. 2) in the fermentation using freshly prepared brine

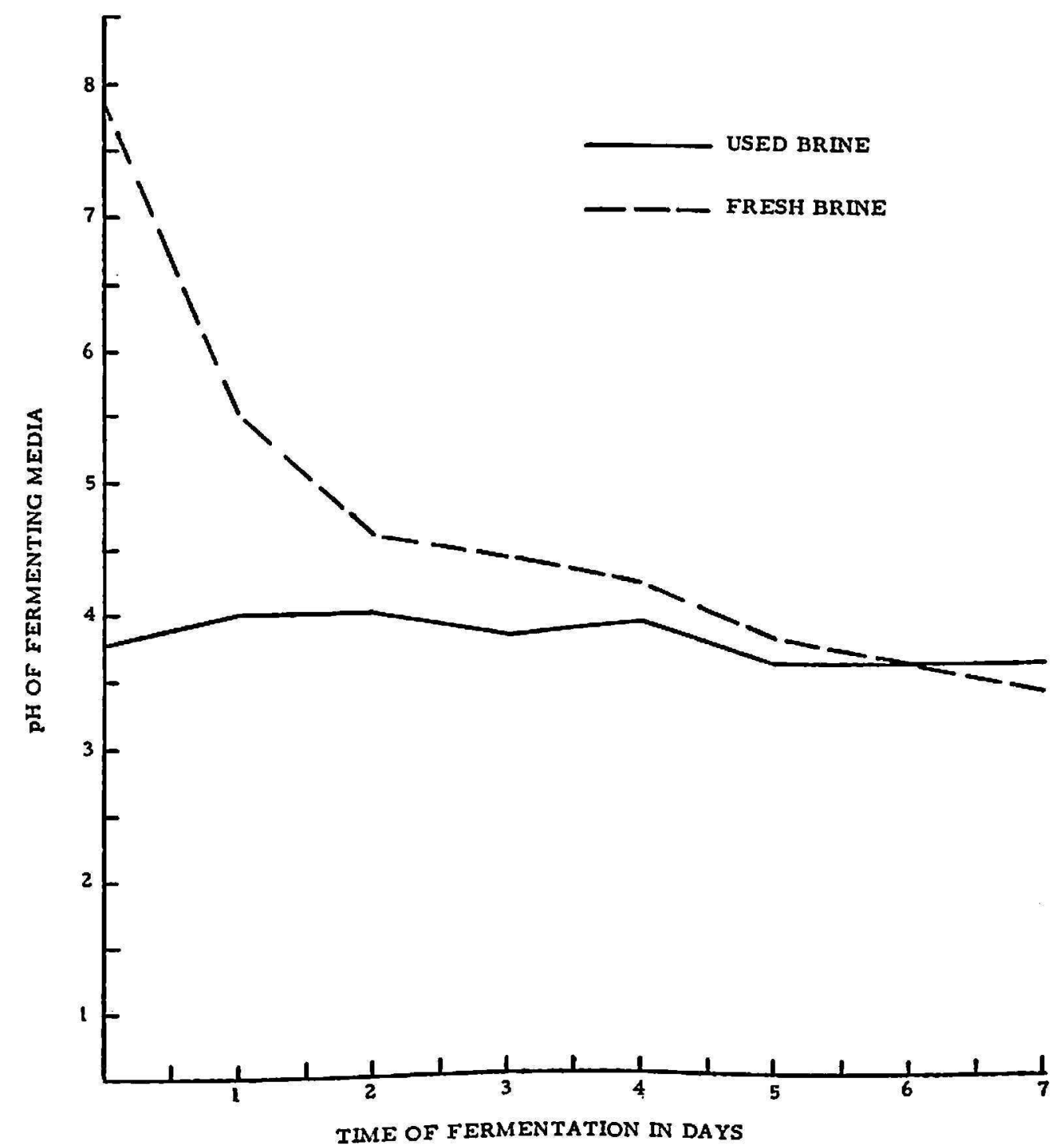

FIG. 1.-Changes in $\mathrm{pH}$ of fermenting media in diced citron curing process when brine is recycled.

follows the curve given by Phillips et al. (7) for cucumber fermentation with 0.1 percent sorbic acid, but in acid concentration it resembles more the values presented by Etchells et al. (3). In the fermentations where the brine was recycled, the acidity started with an approximate value of 0.23 percent and rose to an average value of 0.32 percent, where it stabilized. The lower acid concentrations at the beginning of the fermentations can be accounted by the dilution effect due to the addition of citron. 


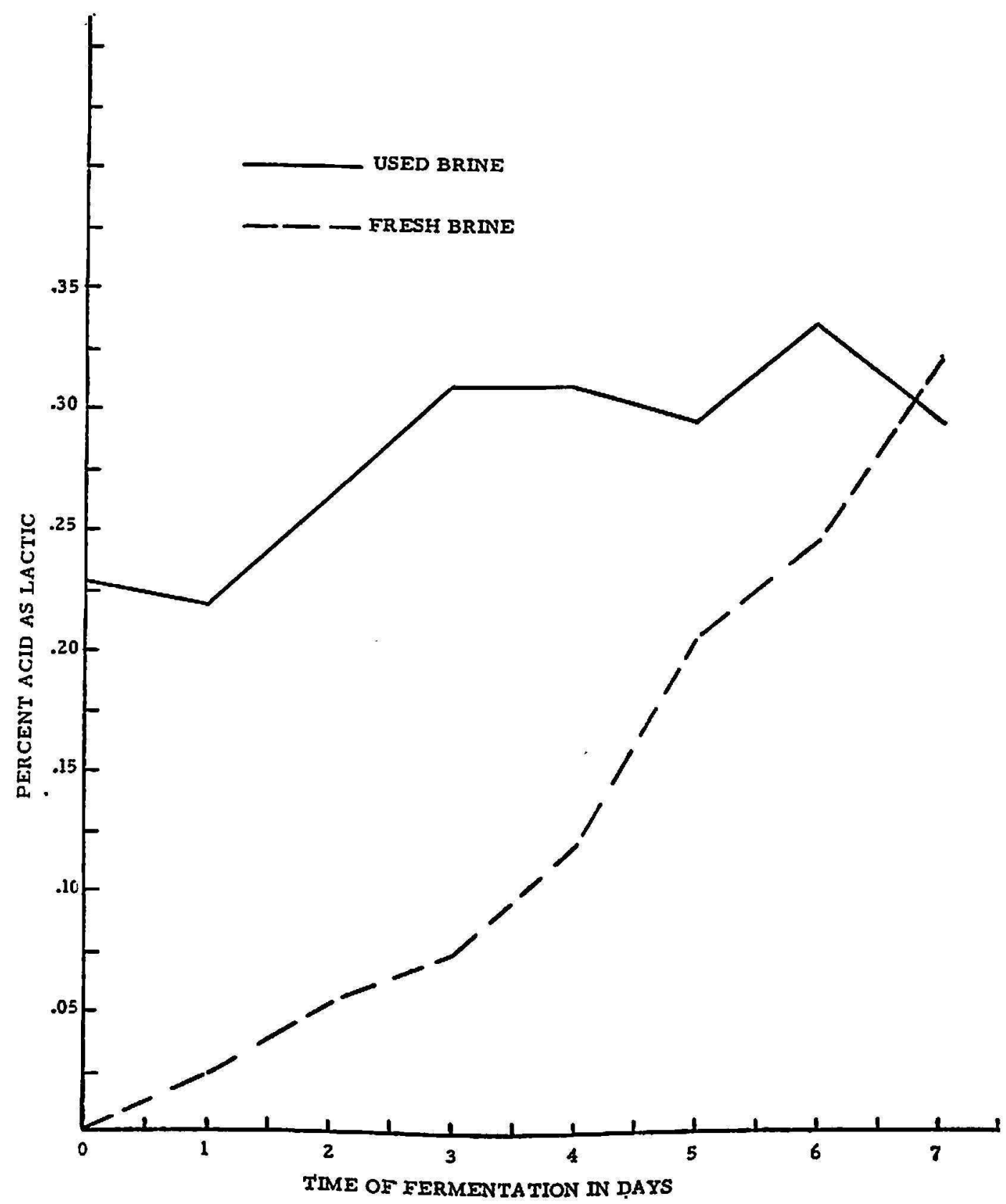

Fia. 2.- Changes in acidity of fermenting media in diced citron curing process when brine is recycled.

Salometer readings (fig. 3 ), which give a relation of the salt concentration show high fluctuations in the first three days, with a tendency to stabilize for the rest of the fermentation period. There seems to be no marked difference in the changes in salt concentration between the fermentation using fresh brine and the one using recycled brine.

Microbiological activity in the recycled brine fermentations is shown in table 1. The initial high mold content found in the 4-day fermentation is explained as accidental, occurring in the handling of the materials and equipment at the beginning of the fermentation. The infection disappeared without affecting the finished product. 
In the centrifugation operation of the recycling process, certain amounts of solids were obtained. The weight of the solids and their relation to the length of the fermentation, the amount of citrons and brine, is presented in table 2.

The separated solids were dried and analyzed for $\mathrm{N}, \mathrm{P}$, and $\mathrm{K}$. The results are presented in table 3. No definite trend appears to exist in $\mathrm{N}$,

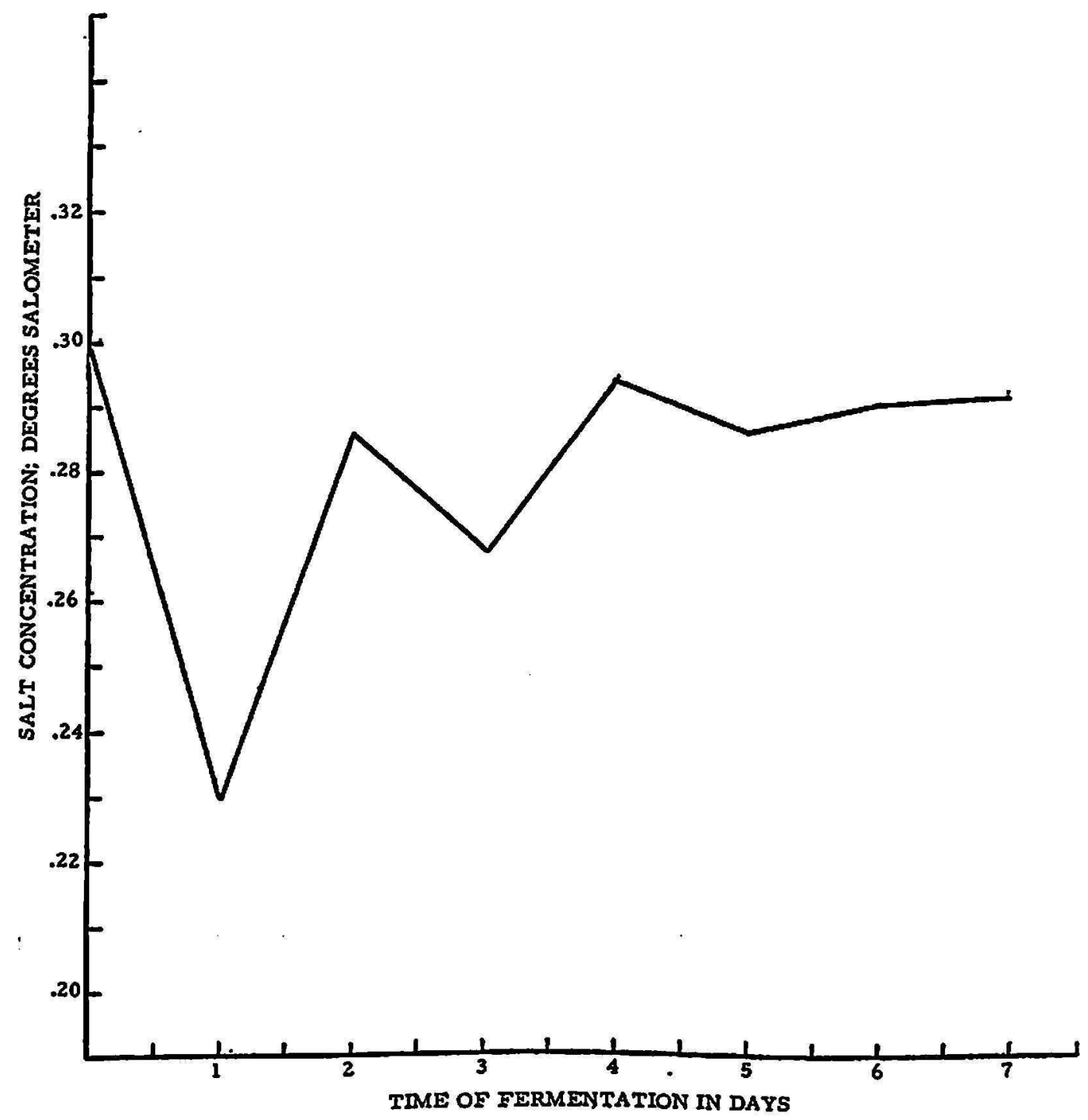

Fig. 3.-Changes in salt concentration of fermenting media in diced citron curing process when brine is recycled.

$\mathrm{P}, \mathrm{K}$ contents of the solids or between these and the duration of the fermentation.

Table 4 shows the amount of salt used in two series of fermentation experiments in which the brine was recycled. The data presented shows a substantial saving resulting from the reusal of the fermenting brine. The saving was calculated and it totals about 78 percent of the amount of salt used normally in a fermentation without brine recycling.

The reusal of the brine and the fermentation of diced citron bring three 
TABLE 1.-Microbial population and activity in diced citron fermentation of $7,4,3$, and $Z$ days when brine recycling is used

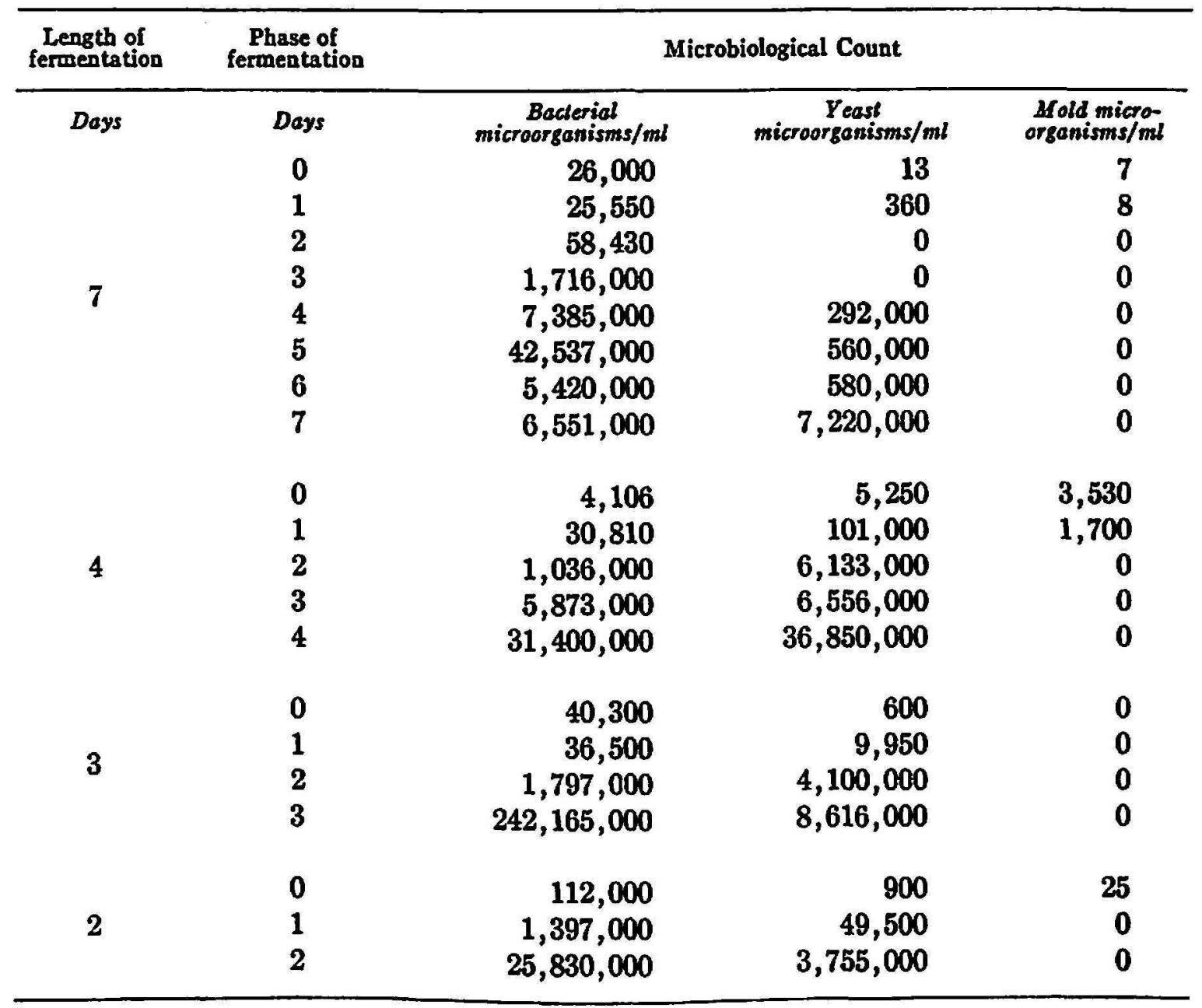

TABLE 2.-Solids separated by centrifugation of the brine at the end of the fermentation process

\begin{tabular}{cccccc}
\hline $\begin{array}{c}\text { Length of } \\
\text { fermentation }\end{array}$ & \multicolumn{2}{c}{ Volume of brine } & \multicolumn{2}{c}{ Weight of citroa } & $\begin{array}{c}\text { Weight of solids } \\
\text { separated } \\
\text { and dried }\end{array}$ \\
\hline Days & Lilers & Gallons & $K_{8}$ & Pounds & Grams \\
7 & 15.1 & 4 & 36.3 & $161 / 2$ & 27.4 \\
7 & 15.1 & 4 & 36.3 & $161 / 2$ & 27.8 \\
7 & 15.1 & 4 & 38.5 & $171 / 2$ & 26.2 \\
4 & 14.2 & $33 / 4$ & 43.5 & $193 / 4$ & 31.0 \\
4 & 14.2 & $33 / 4$ & 42.9 & $191 / 2$ & 26.0 \\
4 & 14.2 & $33 / 4$ & 42.9 & $191 / 2$ & 25.6 \\
3 & 13.2 & $31 / 2$ & 44.6 & $201 / 4$ & 32.8 \\
3 & 13.2 & $31 / 2$ & 44.6 & $201 / 4$ & 25.8 \\
3 & 13.2 & $31 / 2$ & 43.5 & $193 / 4$ & 30.0 \\
2 & 12.3 & $31 / 4$ & 39.6 & 18 & 27.5 \\
2 & 12.3 & $31 / 4$ & 39.6 & 18 & 24.8 \\
2 & 12.3 & $31 / 4$ & 39.6 & 18 & 30.4 \\
\hline
\end{tabular}


TABLE 3.-Nitrogen, phosphorus, and polassium content (dry basis) of solids separated from fermented citron brine

\begin{tabular}{cccc}
\hline Length of fermentation & Nitrogen & Phosphorus & Potassium \\
\hline Days & Percent & Percent & Percent \\
7 & 3.55 & 0.73 & 0.92 \\
7 & 3.60 & .80 & .92 \\
7 & 4.10 & .72 & .90 \\
7 & 4.00 & .70 & .74 \\
4 & 5.00 & .97 & 1.86 \\
4 & 5.20 & .99 & 1.73 \\
4 & 5.30 & .96 & 1.59 \\
4 & 4.50 & .90 & 1.68 \\
3 & 5.20 & 1.10 & 2.76 \\
3 & 4.50 & .94 & 2.00 \\
3 & 4.90 & .98 & 1.95 \\
3 & 4.60 & .89 & 1.96 \\
2 & 4.40 & .96 & 2.15 \\
2 & 4.90 & 1.00 & 2.28 \\
2 & 4.90 & .98 & 2.28 \\
2 & 1.50 & .22 & .60 \\
30 & 3.04 & .30 & .54 \\
Average & 4.59 & .83 & 1.58 \\
Range & $1.50-5.30$ & $.22-1.10$ & $.90-2.76$ \\
\hline
\end{tabular}

TaBLE 4.-Salt used and ils distribution in the fermentation of diced citron

\begin{tabular}{ccccc}
\hline $\begin{array}{c}\text { Length of } \\
\text { fermentation }\end{array}$ & \multicolumn{2}{c}{ Diced citron } & Salt added initially & $\begin{array}{c}\text { Salt added along } \\
\text { fermentation }\end{array}$ \\
\hline Days & $K_{8}$ & $\begin{array}{c}\text { Pounds } \\
\text { First series }\end{array}$ & Grams & Grams \\
& & & & \\
$8^{1}$ & 5.9 & 13 & 1622 & 402 \\
7 & 5.2 & $111 / 2$ & Not needed & 426 \\
4 & 10.7 & $231 / 2$ & 100 & 911 \\
4 & 36.9 & 16334 & 25 & 476 \\
4 & 7.7 & 17 & 25 & 50 \\
3 & 7.3 & 16 & 50 & 475 \\
3 & 5.8 & $123 / 4$ & 50 & 275 \\
3 & 5.9 & 13 & 50 & 240 \\
2 & 6.8 & 15 & 100 & 275 \\
2 & 7.0 & $151 / 2$ & 50 & 400 \\
2 & 7.3 & 16 & 50 & 325 \\
& & $5 e c o n d$ series & & \\
71 & & 18 & 1622 & 330 \\
7 & 8.2 & $131 / 4$ & Not needed & 445 \\
4 & 6.0 & 13 & 25 & 410 \\
4 & 5.9 & 15 & 25 & 350 \\
4 & 6.8 & 16 & Not needed & 480 \\
3 & 7.3 & 17 & Not needed & 300 \\
3 & 7.7 & $161 / 2$ & 25 & 350 \\
3 & 7.5 & 17 & 150 & 400 \\
2 & 7.7 & $161 / 2$ & 200 & 450 \\
2 & 7.5 & $171 / 2$ & 35 & 300 \\
2 & 8.4 & & & 300 \\
\hline
\end{tabular}

1 Fresh brine fermentation. 
definite and important aspects to the citron candying industry: 1) the fermentation time can be shortened to two days; 2) the process can be carried out with about 78 percent savings in the salt used; and 3) the disposal problem of the brine at the end of the fermentation is eliminated.

\section{RESUMEN}

La cidra se cura en una solución de sal al 10 por ciento. En la práctica industrial esta salmuera se descarta una vez terminada la fermentación. En la investigación realizada se encontró que la salmuera se puede usar en fermentaciones sucesivas. El proceso estudiado consiste en centrifugar la salmuera a $12,000 \mathrm{rpm}$, inmediatamente después de terminada la fermentación y añadir la sal necesaria para traerla de nuevo a un nivel de 10 por ciento. En los experimentos llevados a cabo usamos la salmuera 11 veces consecutivas produciendo en todos los casos una cidra curada de buena calidad. El pH, la acidez total y la concentración de sal del medio fermentativo se determinaron cada 24 horas. En el estudio se usó la cidra picada en cubitos de 1/2 pulgada. Se encontró que en las fermentaciones en que la salmuera se recircula, el $\mathrm{pH}$ se mantiene fluctuando cerca de 4 y que la acidez inicial de alrededor de 0.23 por ciento subió hasta fluctuar alrededor de 0.32 por ciento expresado como ácido láctico. La concentración de sal en el medio fermentativo sufre inicialmente una baja y luego, según se ajusta, varía alrededor de un 10 por ciento. Esta baja inicial es atribuible a la absorción de sal por la pulpa de cidra fresca. En el trabajo realizado se llevaron a cabo fermentaciones en cubitos de $1 / 2$ pulgada usando soluciones de sal fresca. Con respecto al $\mathrm{pH}$, la acidez y la concentración de sal, estas fermentaciones se comportaron igual que las fermentaciones para la cura de pepinillos.

Se determinó la población microbiana de las fermentaciones, así como la cantidad de sólidos que se separaba de las salmueras mediante centrifugación, y el contenido de $\mathrm{N}, \mathrm{P}$, y K de los sólidos en suspensión.

El trabajo realizado demuestra que se puede curar cidra usando la misma salmuera consecutivamente y que la fermentación se puede llevar a cabo en 2 días.

El proceso desarrollado le proporciona tres aspectos importantes a la industria de cidra curada: 1) la fermentación se puede hacer en solo dos días; 2) se ahorra un 78 por ciento de la sal a usarse y 3) se elimina el problema de los desperdicios. Estas tres innovaciones representan ventajas fundamentales en el proceso de cura.

\section{LITERATURE CITED}

1. Bell, T. A., Etchells, J. L., and Kelling, R. E., A quick test for cucumber brine acidity, J. Food Sci. 36(7): 1036-38, 1971.

2. Cruess, W. V. and Glickson, D., Observations on brining and candying of citron, Fruit Prod. J. Sept., 17-18 and 125, 1932.

3. Etchells, J. L., Bell, T. A., and Williams, C. F., Inhibition of pectinolytic and cellulolytic enzymes in cucu.nber fermentations by Scuppernong grape leaves, Food Technol. 12(5): 204-8, 1958.

4. - Jone, I. D., and Bell, T. A., Advances in cucumber pickling, U. S. Department of Agriculture Yearbook 229-36, 1951-52.

5. Fellers, C. R., and Smith, E. G., Chemical composition and fermentation studies of citron, J. Agr. Res. 53(11) : 861-67, 1936.

6. Jones, I. D., Salting of cucumbers-Influence of brine salinity on acid formation, Ind. Eng. Chem. 32(6): 858-61, 1940.

. Phillips, G. F. and Mundt, J. O., Sorbic acid as an inhibitor of scum yeast in cucumber fermentations, Food Technol. 4(7): 291-3, 1950. 